\title{
Match Between Pre- and Postmigration Education among New Immigrants: Determinants and Payoffs
}

\author{
Magali Girard \\ McGill University
}

\begin{abstract}
The objective of this paper is to understand the transition between immigrants' premigration education and their educational trajectories once in Canada, and the return on investment in postmigration education in terms of employment status and earnings. The data come from Statistics Canada's Longitudinal Survey of Immigrants to Canada. Using multinomial logistic regressions and fixed effects regressions, we found the following: a third of new immigrants with ostsecondary training pursue their education during their early years in Canada; those who are admitted to Canada because of their high levels of skills, namely the principal applicants in the skilled workers category, are more likely to pursue their education; and those who enrol do not see an immediate benefit in terms of their earnings. This is further evidence of the lack of foreign credential recognition in Canada, which delays entry into highly paid occupations and delays full participation in the Canadian economy.
\end{abstract}

\section{RÉSUMÉ}

L'objectif de cette étude est de comprendre la transition entre l'éducation prémigratoire des immigrants et les trajectoires d'éducation au Canada, et les effets de l'investissement en éducation post-migratoire sur l'employabilité et le revenu. Les données proviennent de l'Enquête longitudinale auprès des immigrants du Canada de Statistique Canada. En appliquant des régressions logistiques multinomiales et des régressions à effets fixes, nous avons constaté que: 1) Un tiers des nouveaux immigrants ayant une formation postsecondaire poursuivre leurs études pendant leurs premières années au Canada, 2) Ceux qui sont admis au Canada en raison de leur haut niveau de compétences, à savoir les demandeurs principaux de la catégorie des travailleurs qualifiés, sont plus susceptibles de poursuivre leurs études, et 3) ceux qui s’inscrivent ne voient pas un bénéfice immédiat sur leur revenu et les chances d'être en emploi. Ceci 
est une preuve supplémentaire de l'absence de reconnaissance des titres de compétences étrangers au Canada, qui retarde l'entrée dans des professions hautement rémunérés et la pleine participation à l'économie canadienne.

\section{INTRODUCTION}

In order to find quality employment and to facilitate recognition of their credentials, immigrants may enrol in a Canadian educational institution, either to find employment in the field in which they were trained prior to migration or to start in a new field. In this paper, direct measures of pre- and postmigration education are used to examine: (a) the link between fields of pre- and postmigration education, (b) determinants, and (c) payoffs to postmigration investment in education. The objective is to test the hypotheses that investment in postmigration education is determined by its link to premigration education, and that employment status and hourly rate of pay change during the first four years in the host country in part because of postmigration education; against the alternative that hourly pay and the likelihood of being employed after four years has not changed. There is a lack of evidence in the literature concerning the link between premigration and postmigration education. As we shall see, most studies have shown that postmigration education moderates the negative effects of foreign human capital on earnings.

\section{LITERATURE REVIEW}

The literature from Canada and elsewhere tells us a few things about postmigration investment in education. First, foreign education offers a low return on the Canadian labour market (Li, 2001; Alboim, Finnie, \& Meng, 2005; Schaafsma \& Sweetman, 2001), compared with schooling acquired in Canada. The rate of return to foreigners without local education depends on the country of origin: the rate of return is higher among immigrants from highly developed countries and countries where English is the main language than among immigrants from less developed countries and countries where English is not the main language (Bratsberg \& Ragan, 2002). Chiswick and Miller (2008) found that in the United States, the payoff to education for adult men who immigrate from English-speaking developed countries is comparable to that of those born in the U.S.

Second, acquiring a local education raises the rate of return on human capital earned abroad. Using data from the 1972 and 1983 Israeli censuses, Friedberg (2000) found that acquiring education in Israel eliminates 50\% of the earning disadvantage between foreign and domestic schooling. Bratsberg and Ragan (2002) argue a U.S. education probably upgrades or validates foreign education: the rate of return on foreign education for those who pursued their studies in the U.S. is almost the same as the returns on U.S. schooling.

Third, postmigration education, whether it is a language course (Renaud \& Cayn, 2006) or vocational training for unskilled immigrants (Stewart \& Hyclak, 1984), helps secure employment. Immigrants with postmigration schooling earn higher wages than those without such education (Bratsberg \& Ragan, 2002).

Fourth, postmigration investment in education varies by country of origin, immigrant category, age at migration, length of time in the host country, and premigration 
schooling and occupation. Birthplace is related to education in the host country: "The greater the degree of skill transferability and the lower the cost of to-and-from migration, the lower the investment in schooling in [the host country]" (Chiswick \& Miller, 1994, p. 173). Duleep and Regets (1999) found a greater investment in postmigration education among Third World than West European immigrants. Like Chiswick and Miller, the authors argue that it is linked to the low initial skill transferability of immigrants from less developed countries.

The research on the effect of category of immigrant (economic immigrants, family-class immigrants, and refugees) leads to a variety of conclusions. Refugees invest more than non-refugees in years of postmigration schooling (Hashmi, 1997), especially in qualifying for a trade (Chiswick \& Miller, 1994). A study concluded that familyclass immigrants in the Netherlands are more likely than labour migrants to make educational investments, because they are less prepared to enter the labour market (Van Tubergen \& Van de Werfhorst, 2007).

Age at migration has a negative effect on postmigration investment in education (Hashmi, 1997; Hashmi, 1987; Chiswick \& Miller, 1994; Van Tubergen \& Van de Werfhorst, 2007; Bratsberg \& Ragan, 2002), and there is a positive relation between postmigration education and length of time in the host country (Chiswick \& Miller, 1994).

There is a nonlinear relationship between premigration schooling and years of postmigration schooling. "Post-migration schooling [...] increases with premigration schooling, but at a decreasing rate" (Hashmi, 1997, p. 300). ${ }^{1}$ Immigrants who were in highly skilled occupations prior to migration were more likely to enrol in postmigration courses than those who were in unskilled occupations (Chiswick \& Miller, 1994). Finally, women are less likely than men to invest in education in the host country (Chiswick \& Miller, 1994).

All studies mentioned above have used data from the U.S. (Borjas, 1982; Hashmi, 1997; Bratsberg \& Ragan, 2002), Australia (Chiswick \& Miller, 1994), the Netherlands (Van Tubergen \& Van de Werfhorst, 2007), Israel (Friedberg, 2000), or Spain (Sanroma, Ramos, \& Simon, 2008). However, some Canadian scholars have used data from the Longitudinal Survey of Immigrants to Canada to study adult immigrants' participation in Canadian education, its determinants (Adamuti-Trache \& Sweet, 2010; Banerjee \& Verma, 2009) and effects on labour market integration (Anisef, Sweet \& AdamutiTrache, 2008; Banerjee \& Verma, 2009). The Longitudinal Survey of Immigrants to Canada followed for four years a cohort of new immigrants who arrived in Canada in 2000 and 2001.

Adamuti-Trache and Sweet (2010) as well as Banerjee and Verma (2009) found that over $40 \%$ of new immigrants participated in education and training during their first two years in Canada. These participants are more likely to be highly educated (Adamuti-Trache \& Sweet, 2010; Banerjee \& Verma, 2009), to be proficient in English or French (Anisef, Sweet, Adamuti-Trache, \& Walters, 2009; Adamuti-Trache \& Sweet, 2010), to not have their foreign work experience accepted (Banerjee \& Verma, 2009; Anisef et al., 2009), to be young (Banerjee \& Verma, 2009), to be male (Anisef et al., 2009), and to have been admitted as principal applicants under the skilled immigrant category (Adamuti-Trache \& Sweet, 2010; Banerjee \& Verma, 2009).

Without distinguishing the type of postmigration education, Banerjee and Verma (2009) found that investment in education predicts the occupational status (whether 
the respondent is working in a professional or managerial job or not) and earnings two years after arrival. Anisef et al. (2008) distinguished between those who enrol in university to pursue their education in the same field as their premigration education and those who pursue their education in a different field. They found that enrolment, whether in the same field or in a different field, significantly reduces the chances of being employed four years after arrival, compared to those who do not pursue their education. As explained by the authors, pursuing a university program requires time; these respondents are probably still in school four years after arrival. They also found that enrolment in a university program, whether it is in the same field or in a different field, leads to higher occupational prestige ${ }^{2}$ four years after arrival.

The current literature using the Longitudinal Survey of Immigrants to Canada does not exploit the longitudinal nature of the data, but rather uses cross-sectional data analysis techniques. A cross-sectional data set includes information of a sample taken at a given point in time, whereas a longitudinal data set includes information (e.g. income, employment status) that has been taken many times for the same respondents throughout the study. It is therefore possible to study the dynamics of change. Longitudinal data analysis has a temporal dimension that cross-sectional data analysis does not have. One of the limits of using cross-sectional data analysis techniques is that they only control for observable factors that have been measured. Some factors known to influence the labour market outcomes of immigrants, such as macroeconomic conditions upon arrival (Aydemir, 2003; Chiswick, Cohen, \& Zach, 1997; Åslund \& Rooth, 2003), have not been used in previous Canadian studies on postmigration education. Fixed effects models, a form of panel data analysis, has the advantage of taking into account unmeasured factors that affect earnings and other labour market outcomes.

Surprisingly, few studies have examined the association between pre- and postmigration education, and, except for Anisef et al. (2008), none has looked at the association between the fields of pre- and postmigration study. The dependent variables often used are years of schooling completed after migration (or a proxy, i.e., difference between total years of schooling and years of schooling outside the host country), and current enrolment status. Yet, knowing whether immigrants are more likely to enrol in an educational program in a different field than their premigration education would be an interesting contribution to the broad literature on foreign credentials for two main reasons. First, new immigrants consider lack of recognition of their foreign education to be one of the main barriers to their economic integration (Schellenberg \& Maheux, 2007). If a good proportion of them enrol in a program in a different field than the one they were initially trained in, that would give us additional information on their integration process. Either they never intended to work in their field, or they enrol in a new program after unsuccessfully attempting to find work in their field. Second, because most immigrants to Canada are selected for their high level of education, it is assumed that those credentials would be of use in the local labour market. Demonstrating high levels of postmigration education investment would support the argument that foreign education is of lower value and would call into question the current selection process of economic immigrants.

This paper wants to fill the gap in the literature on postmigration education by using Canadian data, using fixed effects models, and determining the proportion of new immigrants who pursue their education in the host country, by exploring the as- 
sociation between the fields of pre- and postmigration study, and by looking at the determinants of postmigration investment in education and the returns to postmigration education on earnings and employment.

\section{Research Question and Hypotheses}

How many immigrants pursue their education in Canada, and what are the benefits? The objective of this paper is to understand the transition between immigrants' premigration education and their educational trajectories once in Canada, and the return on investment in postmigration education in terms of employment status and earnings. More specifically,

- how many new immigrants enter an educational program? What proportion enrols in an educational program in the same discipline as their premigration education (e.g., health sciences in both countries)?

- which characteristics influence educational enrolment? Which characteristics influence enrolment in a program in the same field as premigration education or a different one?

- was it worth it? To what extent does a match between pre- and postmigration field of education lead to higher earnings and a greater likelihood of employment?

This study improves on previous research by using longitudinal data and applying multinomial logistic and fixed-effects regression models to understand what predisposes immigrants to enrol in an educational program, considering the link with premigration education, and to look at the payoff to postmigration education in terms of earnings and employment status of new immigrants, four years after landing. The examination of postmigration education may show that many immigrants who are of an age when they might be expected to work in fact go back to school.

Based on the literature reviewed, it is hypothesized that postmigration education is determined by premigration education and other premigration conditions, such as place of education, immigrant category, sex, age, and family status on arrival, and intention to work in Canada. Immigrants who enrol in an educational program in Canada are also expected to earn more and to be more likely to have jobs than immigrants who do not pursue postmigration education.

Immigrants trained in programs that lead to occupations regulated in Canada, such as engineering and teaching, may be more likely to have to repeat all or part of their education in order to be able to work in their field and to have their foreign degrees recognized by the appropriate regulatory body. Also, those trained in a field with low job prospects (e.g. some of the humanities) may be willing to further their education in another area to improve their chances of securing employment and increasing earnings.

There is evidence that those who work in the same field as they did before immigrating earn more than those without an occupational match (Girard, Smith, \& Renaud, 2008). It is expected that the same will be true for education; that those who enrol in the same field are at an advantage thanks to their earlier training. Previous research has demonstrated that domestic schooling increases the rate of return of foreign credentials (Friedberg, 2000; Bratsberg \& Ragan, 2002).

Migrants trained in a less-developed country may have difficulty in getting their degrees or diplomas recognized by Canadian employers and/or regulatory bodies and will therefore be more likely to enrol in educational programs. 
Economic and family class immigrants may be more likely than refugees to invest in their human capital by pursuing their education in Canada, in order to increase their chances of getting a good job. Refugees may not have the means to enrol in educational programs and may therefore be more likely to look for work right away.

Younger immigrants of working age may enrol in educational programs for different reasons than older members of the cohort. They may be more likely to further their education than older migrants with families, who may be more likely to seek employment, even if this means taking a job for which they are overqualified.

Immigrants take language courses to improve their skills in one of the two official languages (English and French). Since a lack of language skills is among the main barriers to employment, taking a language course is assumed to increase earnings and the probability of being employed.

\section{DATA}

The data come from Statistics Canada's Longitudinal Survey of Immigrants to Canada (LSIC), which followed a cohort of new immigrants, aged 15 years and over at the time of landing, who arrived in Canada between October 2000 and September 2001. Six months after their arrival, 12,000 immigrants were interviewed. Four years after arrival, 7,716 were reinterviewed. The sample consists of immigrants who applied for visas at an overseas consulate. The LSIC includes detailed information about education obtained both outside Canada and in Canada, whether language courses, on-the-job training, or formal education.

Since the main research question concerns variations in the hourly pay and employment status over time and determinants of postmigration education, the initial sample comprised all respondents who were still in the sample four years after arrival. It was then narrowed down to respondents aged 25 to 64 at Wave 1 (i.e., six months after arrival), as they are the most likely to have completed school and be working or looking for work. Those who arrived in Canada with more than a high school diploma were then selected. The final sample consists of 4,400 respondents.

The log of hourly rate of pay and the employment status (being employed or unemployed) are the two outcomes measured. The log of hourly rate of pay includes those who are employed as well as those who are not, that is those who have no earnings (coded 0). In their analysis, Friedberg (2000) and Bratsberg and Ragan (2002) used census data and studied employed immigrant men who earned a certain minimum wage. The data used come from a longitudinal survey that follows a cohort of immigrants during their first four years of establishment. Therefore, hourly rate of pay and employment status are time-varying covariates; the majority of the respondents arrived with no pre-arranged employment; their employment rate increased with length of stay in Canada. Because the focus is on new immigrants' early years in the host country, the point of interest is looking at the effect of postmigration education on those who are employed as well as those who are not, and not only on those who successfully secure employment.

Postmigration education is defined as enrolment in the first educational program that can lead to a diploma or degree. Other programs, such as courses that lead to a certificate of completion or leisure courses (e.g., yoga), were excluded. Language training is included as an explanatory variable. 
Field of study includes five categories: education, arts (fine and applied arts, humanities, and social sciences), commerce, sciences (health, agricultural and biological sciences, as well as math and physical sciences) and engineering. Due to low sample size in some categories, a higher level of details was not possible.

Premigration education refers to the highest level of formal education attained outside Canada. The Human Development Index (HDI) is used to assess the effect of country of education. The HDI is a "summary composite index that measures a country's average achievements in three basic aspects of human development: health, knowledge, and a decent standard of living" (United Nations Development Programme, 2009). Because immigrants in the sample arrived in 2000 or 2001, the 2000 HDI is used. When 2000 data were not available for a given country, the 2001 HDI was used. In five cases, neither the 2001 nor the 2000 data were available, so the 2003 data were used.

The three main admission categories are economic immigrants, which include respondents selected for their human capital, plus their spouses and dependents; family class immigrants; and refugees. This analysis makes a distinction between principal applicants and spouses/dependents among economic immigrants, because only principal applicants in the skilled worker category are subject to the point system and that may influence their labour market integration.

\section{METHOD}

To understand the processes involved in pursuing postmigration education, the analysis was conducted in three steps. Bootstrap weights are applied on all results presented. First, a series of descriptive analyses of immigrants in Canada who enrolled in an educational program were performed, including their distribution across various sociodemographic characteristics. Second, multinomial logistic regressions were conducted to understand the determinants of postmigration education, as related to premigration education. In this model, the dependent variable is enrolment in an educational program that is (a) in the same field as premigration education or (b) in a different field.

Third, fixed-effects models were used to determine the effect of postmigration education on earnings and employment status. The advantage of using fixed-effects regression is that it focuses on within-person variation and controls for all variables that are stable over time, such as sex, birthplace, and premigration characteristics, but also unmeasured characteristics. Since the primary objective of the analysis is to examine the effect of immigrants' actions (i.e., investment in postmigration education) on their later economic and occupational situations (within-person variations rather than between-person variations), fixed-effects appears to be the method of choice. Also, Hausman tests revealed that fixed effects are more efficient and consistent models to use over random effects when using hourly rate and employment status as the dependent variables.

\section{RESULTS}

This paper includes three sets of analyses: a series of descriptive analyses of immigrants and of their distribution across fields of postmigration education; a multi- 
nomial logistic regression that examines the likelihood of enrolling in an educational program, as related to the field; and fixed-effect regressions that look at the predictors of hourly pay and employment status.

\section{Descriptive Results}

Table 1 shows that a third of new immigrants with postsecondary education enrolled in an educational program in Canada. This proportion may be compared to that of non-immigrants, and to the immigrants' intentions when they arrived in Canada, as well. The Adult Education and Training Survey, also done by Statistics Canada, reveals that 35\% of adult Canadians (aged 25 to 64, immigrants and nonimmigrants) participated in some type of formal job-related training ${ }^{3}$ in 2002 (Peters, 2004). The result presented in Table 1 is a cumulative proportion of enrolment in an educational program over the first four years after arrival. We can therefore assume that proportionally fewer new immigrants, compared with non-immigrants, engage in some type of formal education in a given year.

Table 1

Enrolment in an Educational Program and Link to Premigration Education, First Four Years after Arrival, Immigrants with Postsecondary Education Aged Between 25 and 64 at Wave 1

\begin{tabular}{lc}
\hline & Percentage \\
\hline Not enrolled & 66.5 \\
Enrolled & 33.5 \\
$\quad$ In same field as premigration education & 2.5 \\
$\quad$ In different field than premigration education & 27.3 \\
$\quad$ Undetermined & 1 \\
TOTAL & 3.7 \\
\hline
\end{tabular}

Note $^{1}$ In some cases, the link between pre- and postmigration education could not be determined, because one field was classified as "Other."

Source: Longitudinal Survey of Immigrants to Canada. Bootstrap weights applied. $n=4,400$.

Using the data from LSIC, and including all types of training (language training and training that does not lead to a diploma or degree), Statistics Canada (2003) showed that, six months after arrival, $70 \%$ of the 25 - to 44 -year-olds and $42 \%$ of the 45- to 64-year-olds planned to further their education or training. This either means that fewer immigrants pursued their education than intended or that many immigrants took language training or a course that does not lead to a degree or diploma.

of those who did enrol in postmigration education, the vast majority did so in a field other than that of their premigration education. It may be that most immigrants who enrolled in an educational program never intended to pursue their education in their initial field, or perhaps they changed fields after failing to find suitable work.

Table 2 illustrates the characteristics of new immigrants enrolled in an educational program. About 57\% of those who pursued formal education in Canada were men and 44\% were women. As explained by Chiswick and Miller (1994), women may be less likely to enrol in an educational program, perhaps because there are fewer women, especially immigrant women, in the labour force. More women than men enrolled in a program in the same field as their premigration education. 
As shown in the literature and here, younger immigrants are more likely to invest in postmigration education. The average age of those who pursued their education was 34, compared with 37 among those who did not.

The average HDI of the country of education is lower for immigrants who enrolled in at least one educational program than for those who did not. This is consistent with the literature, which indicates that the higher the HDI of the country where the highest level of education was obtained prior to migration, the less likely immigrants are to enrol in an educational program in the host country.

Nearly $87 \%$ of new immigrants enrolled in an educational program had a university degree, compared with $80 \%$ of those who were not enrolled. This result demonstrates that (a) a university degree from outside Canada has little value, and/or (b) some number of immigrants take graduate degrees to pursue higher education (e.g., from a bachelor's degree to a Master's degree or PhD).

When we look at the field of the highest level of education achieved outside Canada, there is little difference between the distribution of those enrolled in a program and those not enrolled. But among immigrants in a program, the differences between those in the same field and those in a different field are interesting. Immigrants who came to Canada with a degree in education or in engineering are more likely to pursue their education in the same field. The difficulty in having their foreign credentials recognised by regulatory bodies probably prompts them to further their education once in Canada. The proportions of immigrants in the arts, commerce, and the sciences are higher among those who enrol in a program of a different field, than among those who enrol in the same field. For people in the arts, this confirms the hypothesis that immigrants trained in disciplines with few real or perceived job prospects are more likely to pursue their education in another field once in the host country.

Over 61\% of those who enrolled were principal applicants, compared to 51\% of those who did not enrol. Most family class immigrants did not enrol in an educational program. This is consistent with what has been found in the Canadian literature (Adamuti-Trache and Sweet, 2010; Banerjee \& Verma, 2009). On the other hand, Van Tubergen and Van de Werfhorst (2007) observed greater investments in education among family class immigrants in the Netherlands because, as they say, they are less prepared to join the labour market. Perhaps economic immigrants are more likely to want to find a job, and a highly skilled job, than immigrants in other categories.

\section{Determinants of Enrolments}

Table 3 presents the results of a multinomial logistic model regressing enrolment in an educational program of a particular field of education on the field and level of premigration education, the HDI of the country of education, gender, age, immigrant category, structure of the immigrating unit, and intention of working in Canada. The reference category is "No Enrolment." The coefficient in each column compares with the reference category.

Like Table 2, Table 3 reveals significant differences between fields with regards to postmigration investment in education, this time taking into account other sociodemographic characteristics. All other things being equal, immigrants trained in education and arts are more likely to enrol in a program that is a different field from that of their premigration education. University graduates are more likely than trade school 
Table 2

Enrolment in an Educational Program and Link to Premigration Education, First Four Years after Arrival, Immigrants with Post-Secondary Education Aged Between 25 and 64 at Wave 1, by Socio-Economic Characteristics

\begin{tabular}{|c|c|c|c|c|c|}
\hline & \multirow[t]{2}{*}{$\begin{array}{c}\text { Not } \\
\text { Enrolled }\end{array}$} & \multicolumn{3}{|c|}{$\begin{array}{l}\text { Enrolled in at least one } \\
\text { program }\end{array}$} & \multirow[t]{2}{*}{ Total } \\
\hline & & $\begin{array}{l}\text { Same } \\
\text { Field }\end{array}$ & $\begin{array}{l}\text { Diff. } \\
\text { Field }\end{array}$ & All & \\
\hline \multicolumn{6}{|l|}{$\operatorname{Sex}^{*}(n=4,230)$} \\
\hline Male & 53.6 & 59.8 & 53.4 & 56.5 & 54.6 \\
\hline Female & 46.4 & 40.2 & 46.6 & 43.5 & 45.4 \\
\hline Average age ${ }^{* * *}(n=4,052)$ & 36.5 & 33.5 & 34.0 & 34.0 & 35.7 \\
\hline Average HDI of country of education ${ }^{* * * *}(n=4,052)$ & 0.7339 & 0.7098 & 0.7084 & 0.7098 & 0.7258 \\
\hline \multicolumn{6}{|l|}{$\begin{array}{l}\text { Highest level of education outside Canada**** } \\
(n=4,222)\end{array}$} \\
\hline Trade school or college & 20.0 & 13.4 & 11.8 & 13.1 & 17.7 \\
\hline University degree & 80.0 & 86.6 & 88.2 & 86.9 & 82.3 \\
\hline \multicolumn{6}{|l|}{$\begin{array}{l}\text { Field of highest education outside Canada**** } \\
(\mathrm{n}=4,395)\end{array}$} \\
\hline Education & 9.9 & 17.4 & 7.6 & 8.5 & 9.5 \\
\hline Arts & 22.6 & 6.4 & 20.3 & 19.7 & 21.6 \\
\hline Commerce & 28.1 & 8.9 & 32.5 & 30.3 & 28.9 \\
\hline Sciences & 16.0 & 7.3 & 15.7 & 14.4 & 15.5 \\
\hline Engineering & 23.3 & 60.0 & 23.9 & 27.0 & 24.6 \\
\hline \multicolumn{6}{|l|}{ Structure of immigrating unit ${ }^{* * *}(n=4,230)$} \\
\hline Two adults or more with children & 50.4 & 41.2 & 45.9 & 45.5 & 48.7 \\
\hline Two adults or more without children & 20.1 & 24.5 & 20.6 & 21.1 & 20.4 \\
\hline One adult with children & 3.3 & 3.0 & 4.0 & 3.6 & 3.4 \\
\hline One adult only & 26.2 & 31.47 & 29.5 & 29.8 & 27.4 \\
\hline Planned to work in Canada ${ }^{* * * *}(\mathrm{n}=4,228)$ & 92.9 & 96.2 & 97.0 & 97.0 & 94.3 \\
\hline \multicolumn{6}{|l|}{ Immigrant category*** $(n=4,205)$} \\
\hline Economic Immigrant & 82.3 & 91.1 & 87.6 & 88.4 & 84.3 \\
\hline Principal applicant & 50.8 & 63.5 & 61.0 & 61.1 & 54.2 \\
\hline Spouse or dependent & 31.5 & 27.6 & 26.6 & 27.3 & 30.1 \\
\hline Family class & 15.1 & 7.8 & 8.7 & 9.5 & 13.4 \\
\hline Refugees & 2.7 & 1.1 & 3.7 & 2.8 & 2.8 \\
\hline TOTAL (\%) & 100 & 100 & 100 & 100 & 100 \\
\hline
\end{tabular}

Note. Source: Longitudinal Survey of Immigrants to Canada. Bootstrap weights applied. ${ }^{*} \mathrm{p}<.05,{ }^{* * *} \mathrm{p}<.01$. **** $p<.001$

and college graduates to pursue their education in the same field as their premigration education. These findings corroborate those of Chiswick and Miller (1994), who found a positive relation between years of premigration schooling and years of postmigration schooling.

The HDI of the country of education is negatively related to enrolment in a different field as premigration education. This could be evidence of the low value of credentials earned in countries with a low HDI and of the willingness of immigrants from such countries to upgrade their foreign diplomas or degrees. 
Sex does not significantly influence investment in postmigration education, whether it is in the same field or in a different field as premigration education, when other characteristics are considered. The literature shows that men are more likely to invest in postmigration education but does not relate with premigration education.

As Table 2 and Table 3 show, age is highly correlated to enrolment, whether in the same field or not. Even when level of education and HDI of country of education are controlled for, family class immigrants are less likely than economic immigrants to pursue their education in a different field as premigration education. There are no statistically significant differences according to the structure of the immigrating unit, except between immigrants who arrived in Canada alone and those who arrived with another adult and children. Those who had planned to work in Canada are more likely to pursue their education in a different field, than not pursue their education at all.

Table 3

Coefficient Estimates from Multinomial Logistic Regression on Likelihood of Enrolling in the Same or in a Different Field than Premigration Education, Immigrants aged between 25 and 64 at Wave 1

\begin{tabular}{|c|c|c|}
\hline & Same Field & Different Fi \\
\hline \multicolumn{3}{|c|}{ Field of highest education outside Canada (ref. Commerce) } \\
\hline \multirow[t]{2}{*}{ Education } & $-1.17^{* * *}$ & $0.38^{*}$ \\
\hline & $(0.28)$ & $(0.16)$ \\
\hline \multirow[t]{2}{*}{ Arts } & $-1.06^{* * * *}$ & $0.25^{*}$ \\
\hline & $(0.18)$ & $(0.13)$ \\
\hline \multirow[t]{2}{*}{ Sciences } & 0.07 & $-0.56^{* * * *}$ \\
\hline & $(0.15)$ & $(0.17)$ \\
\hline \multirow[t]{2}{*}{ Engineering } & -0.06 & 0.13 \\
\hline & $(0.13)$ & $(0.13)$ \\
\hline \multicolumn{3}{|c|}{ Highest level of education outside Canada (ref. trade school or college) } \\
\hline \multirow[t]{2}{*}{ University degree } & 0.28 & $0.53^{* * * *}$ \\
\hline & $(0.15)$ & $(0.14)$ \\
\hline \multirow[t]{2}{*}{ HDI of country of education } & $-1.52^{* * * *}$ & $-1.29^{* * * *}$ \\
\hline & $(0.40)$ & $(0.34)$ \\
\hline \multirow[t]{2}{*}{ Female } & 0.08 & 0.21 \\
\hline & $(0.13)$ & $(0.12)$ \\
\hline \multirow[t]{2}{*}{ Age } & $-0.05^{* *}$ & $-0.05^{* * * *}$ \\
\hline & $(0.01)$ & $(0.01)$ \\
\hline \multicolumn{3}{|c|}{ Immigrant category (ref. economic immigrants, principal applicant) } \\
\hline \multirow[t]{2}{*}{ Economic immigrants, spouse or dependent } & -0.13 & $-0.48^{* * * *}$ \\
\hline & $(0.15)$ & $(0.13)$ \\
\hline \multirow[t]{2}{*}{ Family class } & $-0.76^{* * *}$ & $-0.86^{* * * *}$ \\
\hline & $(0.21)$ & $(0.19)$ \\
\hline \multirow[t]{2}{*}{ Refugees } & -0.29 & $0.71^{* * *}$ \\
\hline & $(0.36)$ & $(0.22)$ \\
\hline
\end{tabular}




\begin{tabular}{|c|c|c|}
\hline & Same Field & Different Field \\
\hline \multicolumn{3}{|c|}{ Structure of immigrating unit (ref. two adults or more with children) } \\
\hline \multirow[t]{2}{*}{ Two adults or more without children } & 0.25 & 0.03 \\
\hline & $(0.14)$ & $(0.13)$ \\
\hline \multirow[t]{2}{*}{ One adult with children } & 0.51 & 0.42 \\
\hline & $(0.34)$ & $(0.26)$ \\
\hline \multirow[t]{2}{*}{ One adult only } & $0.36^{*}$ & 0.09 \\
\hline & $(0.16)$ & $(0.14)$ \\
\hline \multirow[t]{2}{*}{ Planned to work in Canada } & 0.25 & $0.57^{*}$ \\
\hline & $(0.28)$ & $(0.26)$ \\
\hline $\mathrm{p}$ & \multicolumn{2}{|c|}{0.0000} \\
\hline
\end{tabular}

Note. Source: Longitudinal Survey of Immigrants to Canada. Bootstrap weights applied. $n=4,000$. Robust standard errors presented in brackets. ${ }^{*} \mathrm{p}<.05,{ }^{* *} \mathrm{p}<.01 .{ }^{* * * *} \mathrm{p}<.001$

In short, these are the social determinants of postmigration education: (a) having studied education or arts, (b) being a university graduate, (c) having studied in a country with low HDI, (d) being an economic immigrant, (e) being young, and (f) having planned to work in Canada. Those who enrolled in a program in the different field as premigration education are more likely to have studied in education or arts.

\section{Returns to Postmigration Education}

The last set of analyses measure the payoffs to investment in postmigration education. Table 4 illustrates the results of four fixed-effects models for which the dependent variable is hourly pay. Table 5 presents the results for the same four fixed-effects models with employment status as the dependent variable. Fixed-effects models focus on within-person variation and control for all variables that are stable over time. Therefore, the models presented in Tables 4 and 5 only include time-varying variables and cannot include time-invariant covariates, such as level of prior education, age, sex, immigrant category, etc.

The result from Models 1 and 2 (Table 4), which contains host country education with no further controls, shows that enrolling in an educational program within four years of establishment, whether in the same field or in a different field than premigration education, does not significantly affect the hourly wage rate. This is a surprising result, given the positive association found in the current literature. This difference may be due to the independent variable or the method used. The measure being used is enrolment, and not completion. One can expect very different results between these two indicators. Had completion of educational program been used, positive effects on hourly rate would have been expected. Nevertheless, this result shows that most new immigrants who arrive with postsecondary education are probably in school four years after landing; some may have entered education a couple of years after their arrival, others may have entered, exited, and re-entered education.

The difference between the results in other Canadian research and those found in the present analysis may also be due to the method used. Banerjee and Verma (2009) used data from the first two waves of LSIC, applied cross-sectional data analysis tech- 
niques, and found a positive association between enrolment in postmigration education and earnings, whereas the present analysis uses fixed effects models and reports no association. To confirm that the different results between the current study and Banerjee and Verma's are due to the method used, OLS regressions were applied only on those who were full-time employed four years after arrival (like in Banerjee and Verma's study). Like Banerjee and Verma, applying cross-sectional data analysis techniques (here OLS) shows a positive association between postmigration education and earnings (results not shown). As said before, fixed effects models control for all timeinvariant covariates, including unmeasured characteristics. It is argued that crosssectional models ignore some important time-invariant characteristics that influence the earnings of new immigrants. Indeed, the following characteristics have not been included in Banerjee and Verma's model and are known to partly determine the earnings of immigrants: the extent of the immigrant social network (Waldinger \& Lichter, 2003) upon arrival, and whether the respondent is working in an ethnic enclave or not (Portes, 1981; Sanders \& Nee, 1987; Zhou \& Logan, 1989).

It might be suspected that the nonsignificant results are due to the fact that the sample includes employed, unemployed, and individuals not in the labour force. The fixed effects regressions were also performed on full-time employed workers four years after arrival, as in other research. The results are also not significant (results not shown). As discussed in the Data section, the point of interest is to study the effect of postmigration education on labour market outcomes of very recent immigrants, including not only those who are employed but those who are unemployed as well.

Table 4

Coefficients from Fixed-Effects Models Regressing Hourly Pay on Enrolment in Educational Program, Language Training, Work Experience, Language Proficiency, and Language Spoken in Province of Residence, Immigrants with Postsecondary Education Aged Between 25 and 64 at Wave 1

\begin{tabular}{|c|c|c|c|c|}
\hline & Model 1 & Model 2 & Model 3 & Model 4 \\
\hline Enrolled in an educational program & $\begin{array}{l}-0.2159^{* * * *} \\
(0.0236)\end{array}$ & & $\begin{array}{l}-0.0581 \\
(0.0260)\end{array}$ & \\
\hline \multicolumn{5}{|l|}{$\begin{array}{l}\text { Link between premigration education and } \\
\text { first educational program (ref. enrolled } \\
\text { in program in same field as premigration } \\
\text { education) }\end{array}$} \\
\hline \multirow[t]{2}{*}{ Not enrolled } & & 0.1920 & & 0.0281 \\
\hline & & $(0.0414)$ & & $(0.0391)$ \\
\hline Enrolled different field & & $\begin{array}{l}-0.0718 \\
(0.0525)\end{array}$ & & $\begin{array}{l}-0.0685 \\
(0.0458)\end{array}$ \\
\hline \multirow[t]{2}{*}{ Enrolled in language training } & & & -0.0598 & -0.0528 \\
\hline & & & $(0.0410)$ & $(0.0444)$ \\
\hline Work experience in Canada (weeks) & & & $\begin{array}{l}0.0086^{* * * *} \\
(0.0002)\end{array}$ & $\begin{array}{l}0.0086^{* * * *} \\
(0.0002)\end{array}$ \\
\hline $\begin{array}{l}\text { Respondent speaks well the main language } \\
\text { spoken in the province of residence }\end{array}$ & & & $\begin{array}{c}0.0523 \\
(0.0313)\end{array}$ & $\begin{array}{l}0.0531 \\
(0.0318)\end{array}$ \\
\hline Observations & 4,398 & 4,398 & 3,952 & 3,952 \\
\hline $\mathrm{p}$ & 0.1949 & 0.4066 & 0.0000 & 0.0000 \\
\hline
\end{tabular}

Note. Source: Longitudinal Survey of Immigrants to Canada. Bootstrap weights applied. ${ }^{*} \mathrm{p}<.05 .{ }^{* *} \mathrm{p}<.01 .^{* * *} \mathrm{p}<.001$ 
In models 3 and 4, enrolment in a language course, local work experience, and proficiency in the language of the province of residence are added to models 1 and 2. Even after controlling for time-varying characteristics, enrolment in an educational program, whether it is in the same field or in a different field, still has no effect on the rate of pay. As expected, local work experience increases the hourly wage rate. Enrolment in language training has no significant effect on hourly rate. Again, completion of a language program would probably lead to a significant positive effect.

Table 5 illustrates the results of fixed-effects regressions on employment status, including the same models as in Table 4. The effects of enrolment in an educational program on employment status are somewhat similar to what is observed for hourly wage. Enrolment in an educational program during the first four years does not affect the likelihood of employment. Continuing in a field of study that is the same or different from what was studied in the country of origin has no effect on employment probability. Anisef et al. (2008) found a positive association between employment status and enrolment in a university program. Again, the difference between the results shown in the present study and those of Anisef et al. may be due to the method used, where they employed cross-sectional data analysis techniques and the current study employs fixedeffects models. Unlike cross-sectional data analysis techniques, fixed-effects models control for all time-invariant covariates, those measured as well as those unmeasured.

Enrolling in a language training program does not influence the probabilities of being employed. Renaud and Cayn (2006) found that completing language training helps to secure employment, among principal applicants from the skilled workers category. Again, the focus of this article is on enrolment and not completion. As expected, local work experience increases the chances of being employed.

Table 5

Coefficients from Fixed-Effects Models Regressing Employment Status on Enrolment in Educational Program, Language Training, Work Experience, Language Proficiency, and Language Spoken in Province of Residence, Immigrants with Postsecondary Education Aged Between 25 and 64 at Wave 1

\begin{tabular}{|c|c|c|c|c|}
\hline & Model 1 & Model 2 & Model 3 & Model 4 \\
\hline \multirow[t]{2}{*}{ Enrolled in an educational program } & -0.1776 & & -0.0824 & \\
\hline & $(0.0141)$ & & (0.0188) & \\
\hline \multicolumn{5}{|l|}{$\begin{array}{l}\text { Link between premigration education and first } \\
\text { educational program (ref. enrolled in program in } \\
\text { same field as premigration education) }\end{array}$} \\
\hline \multirow[t]{2}{*}{ Not enrolled } & & 0.1995 & & 0. 1031 \\
\hline & & $(0.0246)$ & & (0. 0275) \\
\hline Enrolled different field & & $\begin{array}{l}0.0164 \\
(0.0321)\end{array}$ & & $\begin{array}{l}0.0251 \\
(0.0324)\end{array}$ \\
\hline \multirow[t]{2}{*}{ Enrolled in language training } & & & -0.0542 & -0.0593 \\
\hline & & & $(0.0292)$ & (0.0309) \\
\hline Work experience in Canada (weeks) & & & $\begin{array}{l}0.0043^{* * * *} \\
(0.0001)\end{array}$ & $\begin{array}{l}0.0043^{* * * *} \\
(0.0001)\end{array}$ \\
\hline $\begin{array}{l}\text { Respondent speaks well the main language spoken } \\
\text { in the province of residence }\end{array}$ & & & $\begin{array}{l}0.0862 \\
(0.0209)\end{array}$ & $\begin{array}{l}0.0879 \\
(0.0210)\end{array}$ \\
\hline Observations & 4,398 & 4,398 & 3,952 & 3,952 \\
\hline $\mathrm{p}$ & 0.0759 & 0.1926 & 0.0000 & 0.0000 \\
\hline
\end{tabular}

Robust standard errors presented in brackets. ${ }^{*} \mathrm{p}<.05,{ }^{* *} \mathrm{p}<.01 .{ }^{* * * *} \mathrm{p}<.001$ 
The literature suggests a positive link between postmigration education and employment status, as well as higher pay (Bratsberg \& Ragan, 2002; Banerjee \& Verma, 2009). The analyses presented here are different: enrolment in an educational program does not affect the hourly wage rate and employment status; local work experience affects positively the hourly rate and employment status.

\section{DISCUSSION - CONCLUSION}

This paper was driven by three main research questions. The first question is about the proportion of new immigrants who pursue their education in Canada. A third of new immigrants with postsecondary education aged between 25 and 64 enrolled in an educational program during their first four years after arrival. Also, most immigrants who do enrol do so in a program in a field other than their premigration training. It is unclear whether these immigrants never had the intention of working or studying in their field or whether they switched fields after unsuccessful attempts at finding work.

The second question concerns the determinants of postmigration investment in education. The results partly confirm the hypothesis that postmigration education is determined by the field of premigration education. There are few differences between those who enrol in an educational program and those who don't, in terms of field of study prior to migration, but immigrants trained in education and arts tend to study in a different field as their premigration education. As said earlier, immigrants trained in disciplines with fewer job prospects, such as in the arts, are more likely to pursue their education in another field.

Other determinants of investment in postmigration education include having studied in a country with a low HDI and being young. This finding confirms what is found in the literature. Immigrants with credentials from countries with a low HDI are more likely to enrol in an educational program, as their degrees may be less valued on the Canadian labour market. Age is negatively correlated with enrolment, as expected.

The present analysis shows that economic immigrants, especially principal applicants, are more likely to enrol in a program, and principal applicants are more likely to enrol in a different field. Most immigrants to Canada are economic immigrants and are expected to be better prepared to enter the labour market because principal applicants in this category are selected for their high level of education and work experience. It is therefore worrying that most of them pursue their education soon after arrival and do not benefit in terms of their earnings.

Finally, the last question regards the payoffs to postmigration education. Those who enrol in a formal education program do not see an increase in their hourly pay, as expected. That is because they are probably still in school four years after arrival. This is further evidence of the lack of foreign credential recognition in Canada, which delays entry into highly paid occupations and delays full participation in the Canadian economy.

Demonstrating that a third of new immigrants enrol in an educational program shortly after arrival in Canada may call into question the current under-utilization of foreign skills. Such level of enrolment may mean that (a) foreign education is of less value in the Canadian labour market than local education, or (b) because of lack of familiarity with foreign qualifications, employers tend to generalize the qualifications of those immigrants to all immigrants, deeming their work experience and educational 
background to be inferior. As a consequence of either explanation, immigrants pursue their education once in Canada to increase their chances to secure quality employment.

Should Canada invest in assisting immigrants in getting their foreign education recognized in the labour market? If Canada wants to import highly skilled employees, than programs aimed at facilitating the recognition of foreign credentials should be supported. For example, bridging programs offered by universities, often in conjunction with regulatory bodies, mentoring programs that match immigrant professionals with local professionals who can assist them in obtaining a licence, and governmentsubsidized work experience seem to be effectively addressing the issue of foreign credential recognition by getting "at the heart of the problem of immigrant integration into the Canadian labour force" (Birrell \& McIsaac, 2006, p. 134).

Further study on this topic should look at the prevalence, determinants, and effects on earnings and employability of completion of an educational program in the host country. The Longitudinal Survey of Immigrants to Canada, used here, does not enable the study of completion of an educational program because it follows new immigrants during their first four years in Canada only, and the dependent variable would be completion of an educational program that can lead to a diploma, degree, or certificate of completion. Since some educational programs (e.g., bachelor's degree) take three years or more, data from a longitudinal study that follows immigrants over a longer period of time are needed.

\section{REFERENCES}

Adamuti-Trache, M., \& Sweet, R. (2010). Adult immigrants' participation in Canadian education and training. Canadian Journal for the Study of Adult Education, 22(2), 1-26.

Alboim, N., Finnie, R., \& Meng, R. (2005). The discounting of immigrants' skills in Canada: Evidence and policy recommendations. IRPP Choices, 11(2). Retrieved from http://www.irpp.org/fasttrak/index.htm

Anisef, P., Sweet, R., \& Adamuti-Trache, M. (2008). Impact of Canadian post-secondary education on recent immigrants' labour market outcomes. Ottawa: Citizenship and Immigration Canada.

Anisef, P., Sweet, R., Adamuti-Trache, M., \& Walters, D. (2009). See note p 4. Recent immigrants: A comparison of participants and non-participants in Canadian post-secondary education. Retrieved from http://www.cic.gc.ca/english/resources/research/comparison_postsecondary.asp.

Åslund 0., \& Rooth, D.-0. (2003). Do when and where matter? Initial labour market conditions and immigrant earnings. Uppsala, Sweden: Institute for Labour Market Policy Evaluation.

Aydemir, A. (2003). Les effets des cycles économiques sur l'assimilation des immigrants sur le marché du travail. Ottawa: Statistics Canada.

Banerjee, R., \& Verma, A. (2009). Determinants and effects of post-migration education among new immigrants in Canada. CLSRN working paper, 11. Retrieved from http://www.clsrn.econ.ubc.ca/workingpapers.php 
Birrell, B., \& McIsaac, E. (2006). Integrating immigrants to Canada: Addressing skills diversity. In From Immigration to Integration: Local Solutions to a Global Challenge (Chapter 2). Paris: OECD.

Borjas, G. (1982). The earnings of male Hispanic immigrants in the United States. Industrial and Labor Relations Review, 35, 343-353. Retrieved from http://www.hks. harvard.edu/fs/gborjas/Papers/Earnings_of_Male_Hispanic.pdf

Bratsberg, B., \& Ragan, J. F. (2002). The impact of host-country schooling on earnings: A study of male immigrants in the United States. Journal of Human Resources, 37(1), 63-105.

Chiswick, B. R., Cohen, Y., \& Zach, T. (1997). The labor market status of immigrants: Effects of the unemployment rate at arrival and duration of residence. Industrial and Labor Relations Review, 50, 289-303.

Chiswick, B. R., \& Miller, P. W. (1994). The determinants of post-immigration investments in education. Economics of Education Review, 13(2), 163-177.

Chiswick, B. R., \& Miller, P. W. (2008). Why is the payoff to schooling smaller for immigrants? Labour Economics, 15, 1317-1340.

Duleep, H., \& Regets, M.C. (1999). Immigrants and human-capital investment. American Economic Review, 89(2), 186-191.

Friedberg, R. M. (2000). You can't take it with you? Immigrant assimilation and the portability of human capital. Journal of Labor Economics, 18(2), 221-251.

Girard, M., Smith, M. R., \& Renaud, J. (2008). Intégration économique des nouveaux immigrants: Adéquation entre l'emploi occupé avant l'arrivée au Quebec et les emplois occupés depuis l'immigration. Canadian Journal of Sociology, 33(4), 791814.

Goyder, J., \& Frank, F. (2007). A scale of occupational prestige in Canada, based on NOC major groups. Canadian Journal of Sociology, 32(1) 62-83.

Hashmi, A. (1987). Post-migration investment in education by immigrants in the United States (Unpublished doctoral dissertation). University of Illinois at Chicago.

Hashmi, A. (1997). Post-migration investment in education by immigrants in the United States. The Quarterly Review of Economics and Finance, 37, 285-313.

Li, P. S. (2001). The market worth of immigrants' educational credentials. Canadian Public Policy, 27(1), 23-38.

Peters, V. (2004). Working and training: First results of the 2003 Adult Education and Training Survey (No. 81-915-MIE2004015). Ottawa: Statistics Canada

Portes, A. (1981). Modes of structural incorporation and present theories of immigration. In Global Trends in Migration. Staten Island, NY: Center for Migration Studies Press.

Renaud, J., \& Cayn, T. (2006). Un emploi correspondant à ses compétences? Les travailleurs sélectionnés et l'accès à un emploi qualifié au Québec. Montréal: Ministère de l'Immigration et des Communautés culturelles. 
Sanders, J. M., \& Nee, V. (1987) Limits of Ethnic Solidarity. Enclave Economy American Sociological Review. 52(6): 745- 767.

Sanroma, E., Ramos, R., \& Simon, H. (2008). The portability of human capital and immigrant assimilation: Evidence for Spain (IZN Discussion Paper No. 3649). Bonn, Germany: The Institute for the Study of Labor. Retrieved from http://papers.ssrn.com/ sol3/papers.cfm?abstract_id $=1230836 \# \#$

Schaafsma, J., \& Sweetman, A. (2001). Immigrant earnings: Age at immigration matters. Canadian Journal of Economics, 34(4), 1066-1099.

Schellenberg, G., \& Maheux, H. (2007). Immigrants' perspectives on their first four years in Canada: Highlights from three waves of the Longitudinal Survey of Immigrants to Canada. Canadian Social Trends [Special edition]. (Cat. No. 11-008). 0ttawa: Statistics Canada. Retrieved from http://dsp-psd.pwgsc.gc.ca/collection_2007/ statcan/11-008-X/11-008-XIE20070009627.pdf

Statistics Canada. (2003). Longitudinal Survey of Immigrants to Canada: Process, progress and prospects (Cat. No. 89-611-XIE). Ottawa: Housing, Family and Social Statistics Division. Retrieved from http://www.statcan.gc.ca/pub/89-611-x/89-611x2003001-eng.pdf

Stewart, J. B., \& Hyclak, T. (1984). An analysis of the earnings profiles of immigrants. Review of Economics and Statistics, 66(2), 292-296.

United Nations Development Programme. (2009). What is the Human Development Index (HDI)? Human Development Reports. Retrieved from http://hdr.undp.org/ en/statistics/indices/hdi/question,68,en.html

Waldinger, R., \& Lichter, M. (2003). How the Other Half Works: Immigration and the Social Organization of Labor. Berkley: University of California Press.

Van Tubergen, F., \& Van de Werfhorst, H. (2007). Postimmigration investments in education: A study of immigrants in the Netherlands. Demography, 44(4), 883-898.

Zhou \& Logan. (1989). Returns on Human Capital in Ethnic Enclaves: New York City's Chinatown. American Sociological Review, 54 (October), 809-820.

\section{ACKNOWLEDGMENT}

This research was supported in part by grants from the Social Sciences and Humanities Research Council and the Quebec Inter-University Centre for Social Statistics.

\section{CONTACT INFORMATION}

Magali Girard

Department of Sociology

McGill University, Leacock Building

855 Sherbrooke St. West, Montreal QC

H3A 2T7

E-mail: Magali.Girard@gmail.com 
Magali Girard owns a Ph.D. in sociology from McGill University. Her research interests include immigration, labour market and family. The main objective of her dissertation was to look at different aspects of economic integration of immigrants to Canada, and more specifically at issues related to foreign credential recognition. Magali was recently awarded a Canada-USA Fulbright scholarship and a FQRSC postdoctoral research grant to further her research at the University of California-Berkeley.

\section{NOTES}

1. Borjas (1982) and Hashmi (1987) found a negative correlation between pre- and postmigration education, whereas Chiswick and Miller (1994) found a positive relation: they attribute their different results to a measurement error in Borjas' and Hashmi's studies. Chiswick and Miller have a direct measure of postmigration education, whereas Borjas and Hashmi need to estimate it by calculating the difference between total minus premigration schooling. This proxy does not take into account school interruptions before and after migration.

2. Based on the scale of occupational prestige developed by Goyder and Frank (2007). "Higher scores indicate occupations that require higher skill levels associated with higher levels of education" (Anisef, Sweet \& Adamuti-Trache, 2008, p. 21).

3. Formal, job-related training includes courses or programs related to a worker's current or future job. These courses and programs have a structured plan whereby a student, led by a teacher or trainer, follows a planned program and receives some form of formal recognition upon completion, such as a certificate, diploma or degree" (Peters, 2004, p. 6). 